\title{
Sustainability Impact Assessment of Forest Management Alternatives in Europe: an Introductory Background and Framework
}

\author{
Jean-Michel Carnus $^{1}$, Geerten M. Hengeveld ${ }^{2}$ and Bill Mason ${ }^{3}$
}

\begin{abstract}
Adaptation of forest management practices in the context of rapid climatic and socioeconomic changes is a global concern. Stakeholders in the forest-based sector as well as policy makers need improved methods and tools to assess potential impacts of changes in management on sustainability indicators. In this special feature, we introduce a methodological framework for classification of forest management approaches in European forestry and explore how changes in forest management might affect the delivery of various ecosystem goods and services and appropriate sustainability indicators over time and space from local to continental scales. The complementary papers in this special feature explore different aspects of sustainability and risks in representative European forest systems as affected by forest management. We show how a common framework plus supporting growth models and indicators can be used to examine the effects of management on ecosystem services and so provide a first step toward the development of a more integrated approach for strategic forest planning and sustainable use of forest ecosystems.
\end{abstract}

Key Words: ecosystem services; forest management; forest models; indicators; sustainability impact assessment

\section{CONTEXT AND BACKGROUND}

European forests are highly diverse, are increasing in surface area and in volume, and have a long tradition of management to meet a range of social, economic, and environmental needs. The majority of forests within the member states of the European Union (EU) consist of seminatural stands and plantations of indigenous or introduced species. These forests, as well as providing other ecosystem services, are managed to deliver a renewable raw material from which a wide variety of wood-based products are generated in different industrial subsectors, e.g., pulp and paper, bioenergy, sawmilling, panels, packaging, specialty chemicals, etc. EU forests are consequently the foundation for a sector with 16 million forest owners and many enterprises that support the rural economy with more than three million direct jobs. The forest-based sector plays an increasingly recognized role in climate change mitigation and is currently taking measures to adapt to global markets, environmental changes, urban societal demands, and new policy frameworks.

Ever since the Middle Ages, the concept of forest sustainability, in the traditional sense of a sustained yield of wood, has been a leading principle for managing forests in Europe. The main goal was to link the intensity of wood harvesting to forest growth potential to ensure that forests were not overcut and to maintain a continuous supply of timber for various uses. By the end of the 20th century, management of forest resources for multiple uses replaced the previous narrow focus on wood production. The UN Rio Conference on Environment and Development in 1992 used the concept of sustainable development (SD) presented in the Bruntland report in 1987 (WCED 1987), recognized the economic, environmental, and social dimensions of SD, and added forests and forestry to the international agenda because of concerns with deforestation and threats to local communities and biodiversity. Multidimensional aspects of sustainability were embodied in principles of sustainable forest management (SFM), and codified through supporting criteria and indicators (Rametsteiner 2001). More recently, the sustainability paradigm has been extended and new concepts and methodologies have been elaborated to deal with the challenges posed by the need to evaluate the effect of whole economic sectors and value-chains such as the forestry-wood chains (FWC; Päivinen et al. 2012) on sustainable development.

For example, sustainability impact assessment (SIA) methods and tools have been developed to provide an interdisciplinary framework to help ex ante evaluation of new policies or technological innovations according to the three dimensions of sustainability and thus to help implement sustainable development principles. Although this type of approach has been applied to the evaluation of wider land use issues within the EU (e.g., Helming et al. 2011), no previous SIA has been carried out for an entire FWC, although the concepts and indicators for monitoring individual elements of environmental, social, and economic sustainability are very well advanced in the forest sector. In the context of the European FWC, an effective SIA approach needs to consider and integrate not only the whole set of industrial chains and processes using raw materials harvested from the forest but also the range of forest management systems that can be employed (Päivinen et al. 2012) .

The background for all articles in this special feature is the forest resource management component of the EU Sixth Research Framework Programme integrated project EFORWOOD that carried out an initial sustainability impact assessment of FWCs in Europe (Rosén et al. 2012). This 
Table 1. Overview of main tree species and regions considered for defining reference forests within each European biogeographic zone.

\begin{tabular}{cccc}
\hline \hline Boreal & Central Eastern & Atlantic & Mediterranean \\
\hline Picea spp. & Fagus spp. & Picea sitchensis & Pinus spp. \\
Pinus sylvestris & Picea spp. & Pinus pinaster & Eucalyptus spp. \\
Betula spp. & Pinus sylvestris & Eucalyptus spp. & \\
Qüsterbotten (Sweden) & Quercus spp. & Aquitaine (France) & Catalonia (Spain) \\
& Baden-Würtenberg (Germany) & Portugal \\
& Alpine region (Austria) & & \\
& Lorraine (France) & & \\
& Silesia (Poland) & & \\
\end{tabular}

involved the development of a new integrated SIA tool (Lindner et al. 2010) based on four key concepts:

1. Forest-wood chains can be described as chains of processes from the forest to the consumption and end of life of wood products;

2. Sustainability impacts along the chain can be assessed by analyzing indicators of sustainability that characterize processes in the chain;

3. Overall sustainability is quantified by multiplying the relative sustainability indicator impacts of a production process by the amount of material that is handled in this production process;

4. Sustainability indicator results are then aggregated for individual segments or for the whole chain.

Changes in practices, policies, markets, or technologies can affect either the amount of material flow through the chain, the chain structure, the indicator values given for the processes, or combinations of all of these. The papers in this special feature focus on possible changes in forest management and how these might affect the delivery of various ecosystem services and appropriate sustainability indicators.

\section{METHODOLOGICAL FRAMEWORK}

Forest management practices in many parts of Europe are being changed to improve the long-term sustainability of forest resources under shifting environmental and climatic conditions, while at the same time satisfying a wider and often conflicting variety of societal needs and increasing demands for commodities and amenities. However, the wide variety of forest types and the considerable range of management systems used in European countries make it difficult to compare experiences and to predict the impact of changes in management upon sustainability indicators. Therefore, a prerequisite for our work was the creation of a framework for forest management capable of being applied across a wide range of forest types. Such a framework can be used to assess the potential impact of alternative management practices on the three pillars of sustainability at different scales, i.e., local, national, and European, using a common indicator framework.
We provide a brief overview of the overall methodology as an introduction to detailed and specific methodological aspects relevant to each paper of this special feature.

\section{System boundaries}

The forest system boundaries defined corresponded to the area of forested land in EU 25 for the reference year 2005, with possible changes in the future for the years 2015 and 2025 under different scenarios (Arets et al. 2011). Long-term temporal horizons (2050) have been considered in this feature for simulations of future forest resources under different types of management. Within these geographic and temporal boundaries, eight main tree species or group of species were selected over four biogeographical zones, i.e., boreal, central eastern, Atlantic, and Mediterranean, with the objective of covering approximately $80 \%$ of the current wood flow in Europe and to reflect the existing variability of forest productivity and management regimes in Europe (Table 1).

In this special feature, forest systems have been considered at different scales from local and regional levels to national and EU levels. A framework of nine reference forests (Fig. 1) combining selected main tree species and forest types with regional characteristics and boundaries has been defined to develop specific case studies as part of FWC cases for the EFORWOOD project. This framework was used to assess sustainability impacts of forest resource management.

\section{Sustainability indicators}

The existing pan-European criteria and indicator framework for sustainable forest management was developed by the Ministerial Conference on the Protection of Forests in Europe (MCPFE; Freer-Smith and Carnus 2008) and provides a solid basis for SIA of the forest component of FWC, though some domains need further development and elaboration, such as social and cultural values (Edwards et al. 2011a). In addition to MCPFE indicators (MCPFE 2007) and those proposed for whole chain analysis within EFORWOOD (Pülzl et al. 2012), specific economic, environmental, or social indicators have been used in this special feature for the different forest case studies reported in several papers, e.g., marketable wood production, land expectation value, water quality, soil fertility, forest vulnerability, recreational values, etc. 
Fig. 1. Location of reference forests.

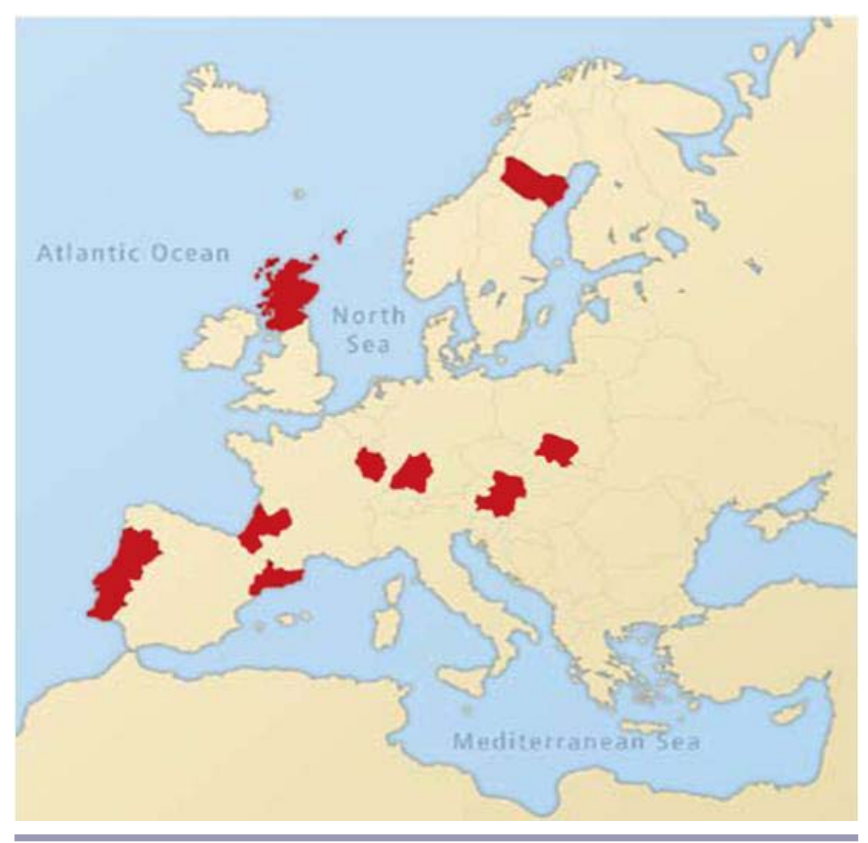

\section{Forest management approaches}

To investigate sustainability impacts of different forest management strategies in the context of current and future FWC in Europe under various scenarios, a conceptual framework of forest management approaches (FMAs) was developed. FMAs are defined by coherent sets of forest operation processes at stand level. Duncker et al. (2012a) identified five FMAs along a gradient of management intensity, i.e., the intensity of manipulation of natural processes, and these FMAs have been used as a supporting framework for all papers in this special feature.

\section{Forest models}

Different types of forest models and simulators can be used and have been recently improved (Tomé and Faias 2011) to predict the development of forest resources and volume production in combination with the prediction of other quantitative sustainability indicators. Those models and simulators are applicable at different spatial scales, i.e., stand, regional, and national, and can be spatially explicit. They are used at stand and local scales in Duncker et al. (2012b), and further described and used in papers by Hengeveld et al. (2012) and Barreiro and Tomé (2012) at EU and national levels.

\section{CONTENT OF THE SPECIAL FEATURE}

Duncker et al. (2012a) set the methodological framework with a classification of forest management approaches in European forestry and show that it can be applied in a wide range of forest types as represented by the reference forests used within
EFORWOOD. Duncker et al. (2012b) consider a virtual forest management unit representative of central European forest ecosystems and look at the synergies and trade-offs between wood production, land expectation value, and a range of ecological services as influenced by forest management. The authors show how a structured methodology for quantifying the interactions between management and particular ecosystem services can help forest managers develop and implement techniques to sustain the delivery of key services. Through a survey conducted in the four bioregions of Europe and scoring of recreational values, Edwards et al. (2012) investigate the interaction between forest type, i.e., conifer, broadleaved, or mixed; stand age; and various forest management alternatives and the consequent effects upon public preferences for sites for recreation. Notably, the authors found that the age of the stand was the key determinant of public preference and that management systems that retained stands to a greater age would be beneficial for recreation. The recreational scoring methodology developed within EFORWOOD (Edwards et al. 2011a) can also generate common datasets to be used in the future for modeling impacts of changes in policies and forest management on recreational values of forests in Europe (Edwards et al. 2011b). A multicriteria risk analysis is conducted by Jactel et al. (2012) to evaluate impacts of FMAs on forest health across Europe, in the context of increasing impacts of biotic, i.e., insects, pathogens, and abiotic, i.e., storms, fires, drought, hazards on forest ecosystems. When considered across eight forest types in Europe, forest management approaches based on very short rotations or on close-to-nature forestry were found to provide lower risks of damage for a range of biotic and abiotic agents. New developments in European and national scale forest resource mapping and simulators are presented in Hengeveld et al. (2012) and Barreiro and Tomé (2012). Hengeveld et al. (2012) use the FMA framework to make the first attempt of spatially mapping forest management practices across Europe and show how this might be used to support more informed policy making. Barrieiro and Tomé (2012) show how improved growth models can be used to inform the discussion about the implications of changes in management such as investigating the increasing use of biomass for energy on wood availability in one particular case study area.

\section{CONCLUDING REMARKS}

At a time when increasing pressures are being placed on forest managers to adapt management practices to meet changing societal demands and projected climate change, it is important that policy makers and other stakeholders in the forestry sector have the tools to examine how possible changes in policy and legislation may affect sustainability indicators, both now and in the future. Carbone (2012) has recently shown how insensitive implementation of forest policies can result in undesirable outcomes that compromise the sustainability of a forest ecosystem. We believe that the papers presented in this 
feature give an indication of how a framework that classifies forest management approaches can be effectively combined with modern models of forest growth and development and linked to a range of quantitative and qualitative indicators of forest sustainability. This provides a means of exploring the impact of changes in management over time and space and to see how policies may enhance or detract from different aspects of sustainability and the risks that may be associated with such developments. In addition, this framework can be used as a unifying 'language' to help researchers and stakeholders involved with different aspects of forest ecosystems and their management arrive at a shared and transparent understanding of key issues. We recognize that these papers are but a first step on the road to developing an integrated approach to sustainable use of forest ecosystems and that there is much yet to do, e.g., applying and validating these approaches at a landscape as well as at a stand level, but we believe that they provide an insight into ways of managing complexity in strategic policy planning and of developing integrated forest planning for delivery of ecosystem services.

Responses to this article can be read online at: http://www.ecologyandsociety.org/issues/responses. php/4838

\section{Acknowledgments:}

We would like to thank all the authors as well as the anonymous reviewers for their efforts in contributing to the papers included in this special feature. The research presented here was carried out as part of the EFORWOOD integrated project funded under the EU Sixth Framework Programme for Research, Technological Development and Demonstration. We are grateful to all the members of the EFORWOOD consortium for their collaboration and for the many helpful and stimulating discussions through the life of the project.

\section{LITERATURE CITED}

Arets, E., T. Paluso, A. Moiseev, G.-J. Nabuurs, D. Slimani, C. Olsmat, J. Lauijssen, B. Mason, D. McGowan, and D. Votter. 2011. Reference futures and scenarios for the European FWC source database. EFI Technical Report 85, European Forest Institute, Joensuu, Finland.

Barreiro, S., and M. Tomé. 2012. Analysis of the impact of the use of eucalyptus biomass for energy on wood availability for eucalyptus forest in Portugal: a simulation study. Ecology and Society 17(2): 14. http://dx.doi.org/10.5751/ES-04642-170214

Carbone, F. 2012. Forestry indemnity: a regional case study. European Journal of Forest Research. 131:119-129. http://dx. doi.org/10.1007/s10342-011-0517-1

Duncker, P. S., S. M. Barreiro, G. M. Hengeveld, T. Lind, W. L. Mason, S. Ambrozy, and H. Spiecker. 2012a. Classification of forest management approaches: a new conceptual framework and its applicability to European forestry. Ecology and Society 17(4): 51. http://dx.doi.org/10.5751/ES-05262-170451

Duncker, P. S., K. Raulund-Rasmussen, P. Gundersen, K. Katzensteiner, J. De Jong, H. Ravn, M. Smith, O. Eckmüllner, and H. Spiecker. 2012b. How forest management affects ecosystem services, including timber production and economic return: synergies and trade-offs. Ecology and Society 17(4): 50. http://dx.doi.org/10.5751/ES-05066-170450

Edwards, D. M., M. Jay, F. S. Jensen, B. Lucas, M. Marzano, C. Montagné, A. Peace, and G. Weiss. 2012. Public preferences across Europe for different forest stand types as sites for recreation. Ecology and Society 17(1): 27. http://dx. doi.org/10.5751/ES-04520-170127

Edwards, D., F. S. Jensen, M. Marzano, B. Mason, S. Pizzirani, and M.-J. Shelhaas. 2011 $a$. A theoretical framework to assess the impacts of forest management on the recreational value of European forests. Ecological Indicators 11:81-89. http://dx. doi.org/10.1016/j.ecolind.2009.06.006

Edwards, D., B. Mason, S. Pizzirani, and M.-J. Shelhaas. 2011b. Approaches to modelling impacts of forest management alternatives on recreational use of forests in Europe. EFI Technical Report 60, European Forest Institute, Joensuu, Finland.

Freer-Smith, P., and J.-M. Carnus. 2008. The sustainable management and protection of forests: analysis of the current position globally. AMBIO 37(4):254-262. http://dx.doi. org/10.1579/0044-7447(2008)37[254:TSMAPO]2.0.CO;2

Helming, K., K. Diehl, H. Bach, O. Dilly, B. Konig, T. Kuhlman, M. Perez-Soba, S. Sieber, P. Tabbush, K. Tscherning, D. Wascher, and H. Wiggering. 2011. Ex ante impact assessment of policies affecting land use, Part A: analytical framework. Ecology and Society 16(1): 27. [online] URL: http://www.ecologyandsociety.org/vol16/iss 1/art27/

Hengeveld, G. M., G.-J. Nabuurs, M. Didion, I. Van den Wyngaert, A. P. P. M. Clerkx, and M.-J. Schelhaas. 2012. A forest management map of European forests. Ecology and Society 17(4): 53. http://dx.doi.org/10.5751/ES-05149-170453

Jactel, H., M. Branco, P. Duncker, B. Gardiner, W. Grodzki, B. Langstrom, F. Moreira, S. Netherer, B. Nicoll, C. Orazio, D. Piou, M. Schelhaas, and K. Tojic. 2012. A multicriteria risk analysis to evaluate impacts of forest management alternatives on forest health in Europe. Ecology and Society 17(4): 52. http://dx.doi.org/10.5751/ES-04897-170452 
Lindner, M., T. Suominen, T. Palosuo, J. Garcia-Gonzales, P. Verweij, S. Zudin, and R. Päivinen. 2010. ToSIA-A tool for sustainability impact assessment of forest-wood-chains. Ecological Modelling 221(18):2197-2205. http://dx.doi. org/10.1016/j.ecolmodel.2009.08.006

Ministerial Conference on the Protection of Forests in Europe (MCPFE). 2007. State of Europe's forests 2007: the MCPFE report on sustainable forest management in Europe. MCPFE, Liaison Unit Warsaw, Warsaw, Poland.

Päivinen, R., M. Lindner, K. Rosén, and M. J. Lexer. 2012. A concept for assessing sustainability impacts of forestry-wood chains. European Journal of Forest Research 131:7-19. http:// dx.doi.org/10.1007/s10342-010-0446-4

Pülzl, H., I. Prokofieva, S. Berg, E. Rametsteiner, F. Aggestam, and B. Wolfslehner. 2012. Indicator development in sustainability impact assessment: balancing theory and practice. European Journal of Forest Research 131:35-46. http://dx.doi.org/10.1007/s10342-011-0547-8

Rametsteiner, E. 2001. SFM indicators as tools in political and economic context: actual and potential roles. Pages 107-130 in R. J. Raison, A. G. Brown, and D. W. Flinn, editors. Criteria and indicators for sustainable forest management. The International Union of Forestry Research Organizations Research Series 7. CABI Publishing, Wallingford, UK. http:// dx.doi.org/10.1079/9780851993928.0107

Rosén, K., M. Lindner, G.-J. Nabuurs, and P. PaschalisJakubowicz. 2012. Challenges in implementing sustainability impact assessment of forest wood chains. European Journal of Forest Research 131:1-5. http://dx.doi.org/10.1007/ s10342-011-0571-8

Tomé, M., and S. Faias. 2011. Report describing the regional simulators and the European simulator. EFI Technical Report 69, European Forest Institute, Joensuu, Finland.

World Commission on Environment and Development (WCED). 1987. Our common future. United Nations World Commission on Environment and Development (chaired by Gro Bruntland), Oxford University Press, Oxford, UK. 